\title{
Finding Political Opportunities: Civil Society, Industrial Power, and the Governance of Nanotechnology in the European Union
}

\author{
ANNA LAMPROU \\ Panswiss Project \\ DAVID J. HESS \\ Vanderbilt University ${ }^{2}$
}

\begin{abstract}
The European Union encourages and institutionalizes participation by environmental, consumer, and labor organizations in the governance of nanotechnology. Interviews with leaders of the civil society organizations (CSOs) show that they identified multiple problems with nanotechnology policy but had only limited success in gaining the changes that they sought. CSO leaders explain their lack of success as due to the overwhelming power of industry and the support of the European Commission for new industrial development, including nanotechnology. We analyze the perspectives of CSO leaders about their difficulties to develop the theory of the political opportunity structure in the situation of a highly scientized policy field with strong industrial monitoring. We suggest the need to extend the theory to pay more attention to the strategies that reformers can use to maneuver in and to open a relatively closed political opportunity structure. We argue that formal stakeholder engagement is not very effective and suggest instead the importance of the following: building coalitions with government actors, threatening or mobilizing grassroots mobilization, making the issue salient to the public, and pursuing the full range of institutional repertoires.
\end{abstract}

\section{Keywords}

nanotechnology; civil society; European Union

Anna Lamprou, Email: anna.lamprou@panswiss.org

=David J. Hess, Email: david.j.hess@vanderbilt.edu

Copyright @ 92016 (Anna Lamprou and David J. Hess) Licensed under the Creative Commons Attribution Noncommercial No Derivatives (by-nc-nd). Available at estsjournal.org. 


\section{Introduction}

Sometimes described as the next industrial revolution, nanotechnology promises a wide range of potential benefits, including improvements in the quality and cost of materials, health care diagnostics and treatment, and energy technology. Whereas governments and the private sector have invested heavily in this new industry, civil society organizations (CSOs)—specifically environmental, labor, and consumer groups-have raised questions about the potential risks and uncertainties associated with materials manufactured at the new molecular scale. Thus, the extent to which nanomaterials should have higher levels of regulatory oversight has become a contentious political issue with divisions between CSOs and the chemical industry.

This study will examine civil society participation in the governance of nanomaterials in the European Union (EU). The EU has facilitated and institutionalized their participation, and the EU has developed a regulatory framework for chemicals that to some degree also institutionalizes the precautionary approach that CSOs have supported. Thus, on the surface there are relatively hospitable or open conditions for CSO participation. However, we show that the civil society participants do not think that they have much influence on central policy issues involving the regulation of nanomaterials, and we analyze their explanations of why they think this is the case. We use their perceptions of their effectiveness and its conditions to contribute the theory of the political opportunity structure (POS). We contribute to the study of the POS by focusing on how reformers find opportunities in a type of POS that is particularly relevant for research in Science and Technology Studies (STS). This type involves the regulation of technology, a scientized policy process, a powerful industry that is heavily involved in monitoring the policy, and a governance process that is relatively open to public participation. We argue that although formal recognition of CSOs as stakeholders in the policy process can be helpful, CSOs must also pursue a broad range of strategies to enhance their capacity to maneuver in and to pry open a relatively closed POS.

\section{Theoretical Background}

As technology in modern societies has become more pervasive and complex, policy fields that develop and regulate new technologies have become more scientized (Drori and Meyer 2006). By "scientization" we mean two main changes: participation in a policy field's governance processes requires a high level of expertise in the relevant science and technology, and the criteria for decision making tend to become narrowed. The narrowing entails excluding broad social values in favor of technical means of evaluation such as risk assessment or cost-benefit analysis (Kleinman and Kinchy 2003). The narrower criteria include issues of safety, health, and environmental effects rather than broader questions such as the societal implications of the widespread diffusion of new technologies. The scientization of a policy field generally raises barriers to entry for individuals and organizations, and it limits the grounds on which legitimate participation is welcomed. In general, the importance of expertise and technical analysis in a policy field can give advantages to industrial organizations because they can bring their teams of scientists to bear on the issues (Sarewitz 2004). 
A potentially countervailing historical change is the tendency for governance processes to include more opportunities for direct public participation. A variety of mechanisms has been developed to allow for public consultation, stakeholder participation, consensus conferences, and other forms of participation that complement the more traditional channels of constituent relations with elected political officials. Some of these mechanisms, such as the consensus conference, help to bridge the gap between a scientized policy field and lay participation. The STS literature has examined these participation mechanisms in some detail, including for the governance of nanotechnology (e.g., Delgado et al. 2010; Groves 2011; Hodge et al. 2007; Levidow and Marris 2001; Philbrick and Barandiaran 2009; Rogers-Hayden and Pidgeon 2007). Much of this work focuses on public participation understood as the consultation of lay individuals, whereas we focus on the public as organized into civil-society public-interest groups.

The EU is a particularly interesting site to study with respect to the problem of public participation by CSOs because there is a relatively high level of institutionalization of their participation (Greenwood 2011; Mahoney 2008; Warleigh and Farbrass 2002). Recognition of CSOs includes official status in governance processes, training and educational support for policy participation, and government funding. We use the term "CSO" with the understanding that there is an ongoing debate over the definition of the term "civil society" in studies of European governance (e.g., Liebert and Trenz 2011). Within this literature our use of the term is oriented toward definitions that focus on the public-interest function of civil society actors (e.g., Ruzza 2004). This public-interest function is linked to the connections between insider CSOs and broad social movements, which in our case include the environmental, consumer, and labor movements. This point is fundamental because as we later suggest, one of the reasons for including CSO participation in governance processes is fear of triggering the contentious politics of social movements that occurred in the case of the public rejection of genetically modified foods (Hagendijk and Irwin 2006). However, there is also a broad concern in the EU across different policy arenas to include CSOs and other non-state actors in governance due to a democracy deficit because only the European Parliament is an elected body (Greenwood 2007, 2011).

We approach the two historical changes of scientization and public participation through the conceptual lens of the POS, which is a central concept in political sociology (Meyer 2004). Approaching the research problem from this perspective is also part of the general integration of political sociological perspectives in STS (e.g., Frickel and Moore 2006). We focus on the two main dimensions of the POS: institutional and configurational. With respect to the institutional dimension, an important distinction in most formulations of the POS is the relative openness or closedness of a government to the calls for reform from social movements and/or insider reformers. In one of the earliest formulations of the central distinction, Kitschelt (1986) suggested that a large number of political parties and an independent legislature increase the openness of the POS. Another important institutional factor is the set of prevailing strategies of political elites, namely, their preference to integrate challengers or to repress and exclude them (Kriesi 2004). Where conditions favor access and integration, reformers have a more "open" set of political opportunities. 
In addition to these institutional factors, the POS also includes the more ephemeral configuration of actors, such as the coalition of parties in power and the structure of the broader political alliances (Kriesi 2004). Most of the literature on the POS that analyzes the configuration of actors focuses on the coalitions between parties on the political left and social movement actors. However, the configuration of actors also includes nonstate actors, and in the case of the governance of industrial technologies, the role of industrial firms and trade associations is quite important. In addition to affecting the governance process through strategies such as lobbying and campaign spending, industry influences the governance process by providing information for regulatory and legislative bodies (Dür 2008).

Finally, analysts of the POS note that the structure of institutional relationships and the configuration of actors are not in themselves sufficient to explain mobilization patterns and outcomes. Rather, advocates and activists interpret these conditions and make judgments about what strategies for political change are most likely to be successful and where the potential leverage points are in the POS (McAdam et al. 2001). Thus, the analysis of the POS requires attention to the meanings that reformers attribute to the POS and to the strategies that they develop in light of their interpretations (Kriesi 2004). We focus on this issue and the problem of finding how activists perceive opportunities for leverage within the POS. Thus, we are interested in the active processes of attempting to open the POS and to find opportunities within existing configurations of the POS.

In the case of the governance of nanotechnology in the EU, the pattern of contradictory factors does not enable the POS to be described as either open or closed. On the one hand, the EU governance process, like that of some of its influential member states, tends to be characterized by a high level of cooperation and consensual decision-making, in contrast with the more conflictual style of American politics (Badaracco 1985; Daemmrich and Krücken 2000; Jasanoff 1986; Mahoney 2008; Vogel 1986). Furthermore, the high level of cooperation required among the units of the EU system tends to increase autonomy for government officials, and research on the influence of business on EU policy outcomes suggests that it is sometimes in a defensive position (Dür et al. 2013). Especially in the case of nanotechnology policy, there was a concerted effort to include CSOs in the governance process. Thus, there are strong suggestions that the POS would be relatively open to CSO participation and to influence in the governance process.

On the other hand, the policy field is highly scientized, the industry under regulation is large and powerful, and the political and industrial elites agree that there is a need for a policy framework that supports industrial innovation and competitiveness. Furthermore, industry has substantial financial resources that it can use to influence all aspects of the governance process from legislation through implementation. Although there is variation across policy issues in the degree to which industry groups can influence EU policy (Ruzza and Bozzini 2008; Mahoney 2008), one factor is the size of the industry's presence in Brussels. A review of the staff sizes of the leading business associations in Brussels showed that the European Chemical Industry Council (CEFIC) is the largest association and three times larger than the second largest one (Greenwood 2011). Furthermore, there are general political concerns in the EU that favor technological 
innovation as a strategy of economic renewal, and support for nanotechnology is part of this general political goal.

Thus, the study of the role of CSOs in the governance process can shed light on how the POS works in a scientized policy field where the industry is powerful and engaged in the policy process. On the one hand, institutionalized processes that support public participation from the CSOs should give them an influential voice in the governance of nanotechnology. On the other hand, the policy field is highly technical, carefully monitored by industry, and supported by a broad political consensus in favor of innovation and technological development.

We use this case study of the governance of nanotechnology in the EU to provide some insights into the conditions under which CSOs attempt to gain successful policy outcomes in a partially open and partially closed POS. By "success" we mean the capacity to bring about appropriate solutions to policy problems that the CSOs identify as important. In providing an analysis of the POS for CSO participation in the governance of nanotechnology in the EU, we follow the methodological caveat discussed above, namely that it is important to track how the reformers interpret the POS. Thus, we focus on what the CSOs perceive to be important issues and outcomes and on how the CSOs interpret the different factors that lead to successful or unsuccessful outcomes.

\section{Empirical Background: EU Nanotech Regulation and Civil Society Participation}

In the EU since 2007, nanomaterials fall mainly under the regulatory framework of Registration, Evaluation, Authorization and Restriction of Chemical Substances (REACH), which is overseen by the European Chemical Agency (ECHA). Other regulatory frameworks apply for specific nanotechnology uses, such as for food, drugs, and cosmetics. However, because REACH was developed for bulk chemicals based on existing scientific knowledge and classification, nanomaterials were not subject to regulation per se, that is, due to their nanoform. Thus, CSOs have drawn attention to important regulatory gaps in the REACH framework.

The REACH framework requires manufacturers and importers of chemical substances to prove that their products are safe by developing risk assessments for their chemicals, a costly procedure that regulatory agencies previously had to fund. REACH also requires information disclosure about all substances, new or existing, that are on the market. Regulation is divided between phase-in and non-phase-in substances. The latter are new chemicals that have not been available or manufactured on the EU market before 2008. Manufacturers or importers of nonphase-in substances need to register those chemicals with the ECHA before they manufacture them or import them. Phase-in substances also have later registration deadlines according to their production volume. Because all chemicals require registration, $\mathrm{REACH}$ is sometimes characterized as a precautionary approach to chemical regulation.

In the case of nanotechnology regulation, the relevant units of the EU governance structure are the Parliament, the Commission, and the Council of the European Union. Only the EU parliament is directly elected; the other legislative body, the Council of the European Union, consists of the ministers of the member states (varying by issue), and the executive body, the 
European Commission, consists of commissioners from the member states. In order to compensate for the democracy deficit, the EU granted more rights to the EU Parliament, and with the Lisbon Treaty the EU Parliament became co-legislator with the Council (Trenz et al. 2011). Another response was to include CSOs officially in political decision making (European Commission 2001; Greenwood 2011).

In the case of nanotechnology regulation, a group of six CSOs constitutes the leading actors with respect to institutionalized participation in nanotechnology governance. They are the European Environment Bureau (EEB); the Center for International Environmental Law (CIEL); ClientEarth, another environmental law organization; the Bureau Européen des Unions de Consommateurs (BEUC), or European Consumers Bureau; the BUND (Friends of the Earth Germany); and the European Trade Union Confederation (ETUC). This group of organizations represents more or less the universe of labor, environmental, and consumer organizations that are involved in nanotechnology policy at the EU level. (See Table 1.) Of the six organizations, only CIEL, ClientEarth, and the ETUC actively work on REACH and nanomaterials at the EU level. However, EEB appears at the majority of meetings and working groups because many environmental organizations work together with EEB as the umbrella organization, and it has been the source of several important reports on nanotechnology policy (Fedrigo \& Senjen 2010; Senjen 2009a, 2009b, 2009c). As a result, EEB is included as one of the active organizations in $\mathrm{REACH}$ and nanotechnology regulation. All of the six organizations work closely together and have so many opinions and requests in common that it is sometimes hard to distinguish their positions.

There are various mechanisms, both formal and informal, that allow CSOs to participate in the governance of nanotechnology. First, the EU encouraged CSO participation by providing support for the "Nanotechnology Capacity Building NGO" (NanoCap). The project ran from 2006 to 2009 and was developed along the lines of consensus conferences. Unlike the traditional consensus conference, the NanoCap project included CSOs rather than lay individuals, and the objective of encouraging CSOs to develop a position was more open-ended than the goal of arriving at a consensus statement (European Environmental Bureau 2009). The project was carried out through five working conferences, with each focused on a different aspect of nanotechnology. Universities were responsible for introducing and explaining the issues, and CSOs then discussed the issues and formulated their own positions (Broekhuizen and Reijnders 2011). Because the Commission is not an elected body, it has a democracy deficit that it attempts to neutralize by having formal mechanisms for public and stakeholder consultation periods before the passage of a law. Thus, CSOs, like industrial associations, have formal recognition of access to the Directorate General (DG) Environment and to DG Grow (formerly DG Enterprise, now DG for Internal Market, Industry, Entrepreneurship, and SMEs), which are the two directorates that are responsible for the implementation of REACH. CSOs also have access to the European Parliament, but because of the complexity of the regulatory issues, only a handful of members of Parliament are knowledgeable enough to lead on the nanotechnology issue, and some of the leaders are members of the Green Party. The Green Party is known to complain publicly about the way that the Commission and the ECHA have handled nanotechnology 
regulation and their failure to take action. The Green Party has informal relationships with CSOs that involve exchanges of information and strategy about what the Commission has not done. The CSOs also have access through the ECHA. The ECHA has various committees that discuss different issues and represent different interests, including a committee of socio-economic analysis, which advises the ECHA on the socio-economic impact of possible legislative decisions regarding the processes of restriction and authorization of specific substances. The ECHA's activities are closed to the public, but the expert groups and more importantly the management boards have members representing CSOs.

\begin{tabular}{|c|c|c|c|}
\hline Organization & Description & Funding & Strategies \\
\hline BEUC & $\begin{array}{l}\text { EU-level } \\
\text { environmental } \\
\text { consumer } \\
\text { organization }\end{array}$ & $\begin{array}{l}\text { Mainly member } \\
\text { organizations, also EU } \\
\text { funding }\end{array}$ & $\begin{array}{l}\text { Advocacy and monitoring of } \\
\text { EU consumer policy as umbrella } \\
\text { organization }\end{array}$ \\
\hline BUND & $\begin{array}{l}\text { German } \\
\text { environmental } \\
\text { organization } \\
\text { (Friends of the } \\
\text { Earth) }\end{array}$ & $\begin{array}{l}\text { Member contributions, some } \\
\text { support from German } \\
\text { government }\end{array}$ & $\begin{array}{l}\text { Advocacy and monitoring of } \\
\text { EU policy of chemicals and } \\
\text { REACH in general }\end{array}$ \\
\hline CIEL & $\begin{array}{l}\text { Uses international } \\
\text { law to protect health } \\
\text { and environment }\end{array}$ & $\begin{array}{l}\text { Private foundations, some } \\
\text { government grants }\end{array}$ & $\begin{array}{l}\text { Consulting, policy research, } \\
\text { legal counsel }\end{array}$ \\
\hline ClientEarth & $\begin{array}{l}\text { Nonprofit } \\
\text { environmental law }\end{array}$ & $\begin{array}{l}\text { Mostly private foundations, } \\
\text { some EU funding }\end{array}$ & $\begin{array}{l}\text { Litigation (e.g., lawsuit against } \\
\text { ECHA on disclosure of data) }\end{array}$ \\
\hline EEB & $\begin{array}{l}\text { EU-level } \\
\text { environmental } \\
\text { umbrella } \\
\text { organization }\end{array}$ & $\begin{array}{l}\text { Members, EU funding, } \\
\text { foundations, other } \\
\text { governmental and } \\
\text { intergovernmental } \\
\text { organizations }\end{array}$ & $\begin{array}{l}\text { Advocacy and monitoring of } \\
\text { EU environmental policy }\end{array}$ \\
\hline ETUC & $\begin{array}{l}\text { EU-level labor union } \\
\text { umbrella } \\
\text { organization }\end{array}$ & $\begin{array}{l}\text { Membership fees and EU } \\
\text { funding }\end{array}$ & $\begin{array}{l}\text { Advocacy and monitoring of } \\
\text { EU labor and environmental } \\
\text { policy }\end{array}$ \\
\hline
\end{tabular}

Table 1: Summary of Main Civil society Organizations in EU Nanotechnology Policy

\section{Research Questions and Analytic Strategy}

The research project seeks to understand the policy priorities that the CSOs have articulated and how they understand the POS and the opportunities for action within it. Specifically, we ask two questions: 
1. What policy problems do the CSOs identify for the governance of nanotechnology, and how do they perceive their effectiveness at achieving their proposed solutions?

2. How do the CSOs perceive the POS and the opportunities for gaining influence?

These are descriptive questions, which are best addressed by ethnographic, qualitative methods that show how the CSOs interpret the POS. Because we focus on the perceptions of CSO representatives, the interviews were focused primarily on them $(\mathrm{N}=20)$. The research is secondarily based on the analysis of official governmental and CSO documents available on the web sites of the EU and the CSO organizations, and it also draws on participant-observation in the European Environmental Agency and in meetings in Brussels of CSOs involved in nanotechnology policy. Although a few interviews $(\mathrm{N}=8)$ were conducted, when granted, with government officials, interviews were not conducted with industry representatives. It might be interesting to know their perceptions of problems with the governance of chemicals, but a full exploration of their views on the governance of nanotechnology is outside the scope of the present study.

\section{Results}

\section{Policy Problems and Experience}

With respect to the first research question, CSOs identified a range of policy problems and solutions for the governance of nanotechnology. By far the most important was achieving a definition of nanomaterials that would distinguish similarly structured chemicals from bulk materials and that would lead to specific assessment procedures that were appropriate for nanomaterials. In the EU all chemicals will be registered eventually, but REACH does not distinguish between bulk substances and nanomaterials. All CSO representatives stated that the lack of a specific definition of nanomaterials, and hence a specific regulatory guideline for the assessment of nanomaterials, was the central regulatory problem, and interviews tended to focus on this goal. A closely linked problem was the need to close loopholes for nanomaterials, and interviewees frequently mentioned the tonnage exemptions. The REACH tonnage trigger was set at one ton for the lowest level, below which substances are not subject to registration. Interviewees argued that the minimum trigger was too high (inadequate) given the low weight of nanomaterials. Furthermore, no toxicological, ecotoxicological, or exposure information (required only for substances of very high concern) was required, because such information was assumed to be known and transferable from the parent bulk substance.

Other problems fell more into the area of process and transparency. For example, CSO representatives noted that the ECHA did not publish information that should be public under the Directive 2003/ 4 IEC on public access to environmental information, and furthermore the agency had very poor data. They also raised concerns about the fact that ECHA did not check the information provided by the industry and that industry could easily enter inaccurate information. For example, they noted that the ECHA checks only 5\% of the dossiers (Buonsante 
2011). More generally, CSO representatives also complained about the reliance of the ECHA on memos from the Commission that were not made available to the public.

Of these policy problems, the only areas that CSOs described as having achieved a partial victory were gaining some clarity on the registration process and achieving a definition of nanomaterials. With respect to registration, the Center for International Environmental Law (2015) welcomed as improvements the amendments proposed by the European Commission in 2014 but expressed ongoing concerns with inadequate processes of registration. These changes were made possible by having a definition of nanomaterials, which was the paramount policy goal of the CSOs and the one that they described as an important if partial success. We focus on the process of achieving the definition because it provides some insights into how the CSOs were able to gain some recognition of their position within the partially open POS.

Achieving a clear definition for nanomaterials is a highly technical matter, and it is not always obvious even to the CSOs how the boundaries between nanomaterials and nonnanomaterials should be constructed. The common definition is based on the size of the particle, but even size is complicated because the size varies across the dimensions of a particle. Furthermore, one trade union representative commented how the definition of nanomaterials might vary between soluable and nonsoluable chemicals, between carcinogens and noncarcinogens, between coated and uncoated particles, and for various other properties that need to be taken into consideration in coming up with a definition. He added, "If you have a very wide definition to ensure that no nanomaterial is excluded, then many materials are included which are not really nanomaterials, so we will have many false positives." Furthermore, there are similar problems with assessment. As a representative from BUND put it, "Can you test nanomaterials in the same way as bulk materials, or do you have to test them differently?"

Nevertheless, the CSOs advocated for a definition of nanomaterials and for nanoappropriate assessment procedures. This issue erupted into a conflict in 2008, when the European Commission (2008) published a paper that argued that nanomaterials were included under existing regulations and did not require registration as new substances if they had a similar structure to existing bulk chemicals. In response, the European Parliament (2009) passed a resolution that disagreed with the European Commission's view that current regulatory framework covered in principle the risks of nanotechnology. Instead, Parliament called on the Commission to develop a "science-based definition of nanomaterials" among other changes. In 2009 the ECHA developed and ran three REACH Implementation Projects on Nanomaterials (RIP-oNs), one on substance naming and identification, RIP-oN1, and two that addressed assessment procedures, RIP-oN2 and RIP-oN3. CSOs participated in the more important RIPoN1, whereas the other two processes were highly technical, and the CSOs were not involved. For the RIP-oN1 process, EEB and ETUC participated along with representatives of industry, the ECHA, and member state authorities. The process led to a relatively high level of agreement among member states, the ECHA, and the CSOs regarding size and surface treatments as identifiers (Joint Research Center 2011). However, industry maintained that chemical structure should be the only identifier, and because agreement could not be achieved with industry 
representatives, the final report ended up discussing different options rather than providing a coherent recommendation.

The European Commission (2011) then admitted that special guidelines might be needed and developed a definition for nanomaterials, but it maintained that REACH was the appropriate framework. In a response to a second communication paper from the European Commission (2012), CSOs argued that even though the Commission's working paper acknowledged the existence of possible risks that nanomaterials might pose and the fact that REACH did not adequately regulate nanomaterials, the Commission considered only a minimal amendment to the REACH annexes, which would not close the existing loopholes. In contrast, the CSOs argued that "when information is lacking on the toxicity of a substance, rather than assuming that no data means no harm, the Commission should enforce a precautionary approach and regulate the production and collection of data, and adequately restrict, ban, or tightly regulate the marketing of the substance concerned" (European Environmental Bureau et al. 2012).

The Commission's definition of nanomaterials fell short of the goals established by the CSOs. For example, BEUC, CIEL, and EEB expressed their disappointment about the cut-off limit for a material to be identified as nanomaterial. The recommendation set this limit at $50 \%$, meaning that if $50 \%$ or more of the particles in the distribution of an aggregate material are in the size range $1 \mathrm{~nm}$ to $100 \mathrm{~nm}$, then the material is considered a nanomaterial. In contrast, the initial proposal by DG Environment and the CSOs was to define the aggregate as a nanomaterial if more than $1 \%$ of the particles met the size criterion. In a press release EEB stated, "The European Environmental Bureau (EEB) is deeply disappointed by the European Commission's decision released today to use a narrow definition for the term 'nanomaterial,' indicating that industry lobbying has won over the Commission's own scientific advisors"' (Duprez 2011).

In summary, the case of the definition of nanomaterials provides some insight into how CSO participation can work in a POS that is open to participation but highly scientized and heavily influenced and monitored by industry. The case shows that the CSOs were able to participate in the governance process, and in coordination with Parliament they were able to nudge the Commission toward developing a definition that was a precondition for assessment. Thus, the POS was open to CSO participation, but this did not mean that their views were reflected in final policy, and they did not participate in the more scientized policy arenas such as the RIP-oN2 and RIP-oN3. To gain influence over the process for the definition of nanomaterials, the CSOs formed an alliance with Parliament and especially with the Green Party within Parliament. However, the case also shows the limitations of the influence of both the CSOs and of Parliament because the definition was tilted toward industry preferences. CSO leaders also expressed dissatisfaction about the lack of progress on other policy problems as discussed above.

\section{Perceptions of the POS}

$\mathrm{CSO}$ representatives explained their ability (or lack thereof) to influence the governance process as based on a combination of factors that can be classified in terms of the configurational and institutional dimensions of the POS. With respect to the configurational dimension, interviewees 
noted that industry representatives have the financial ability and expertise to participate in every aspect of the governance process. Furthermore, because the issue is so technical, the Commission depends heavily on knowledge and information supplied by the chemical industry, and industrial influence operates through the provision of technical expertise in addition to lobbying. A representative of the trade unions noted that industry organizations "are quite influential...because they have experts and they have much more resources than we have." Furthermore, a representative of an environmental CSO described the revolving door as "quite a problem" because "very often someone from CEFIC, which is the lobby for the chemical industry, just steps from there to the Commission." The CSOs also believed that the ECHA is concerned with the risk that its decisions may anger industry. For example, a representative of the environmental NGOs commented, "The ECHA seems to be very much in a defensive mode, and they are scared of doing something wrong and getting something from the industry."

In contrast, the CSOs lack comparable resources. For example, an environmental CSO recognized that "NGOs do have more access now" and said "that's a good thing." However, he added:

You also need the resources to use this access to participate, for instance, in the riskassessment committee or in the RIP-oN on nanomaterials....If you only have the resources to go there and listen but not to participate actively, then, of course, you haven't won a lot. So that's maybe a problem that hasn't been solved yet.

Although there are members of the CSO community who have enough policy expertise to participate, often they are involved in a broader range of issues related to chemical regulation, and they are unable to work actively with all branches of the government. Thus, although the governance process is open to CSO perspectives and participation, the CSO representatives point to their chronic lack of resources, including expertise, as an important barrier to effective participation.

Although the NGOs perceived the configurational dimension of the POS to be relatively closed due to the greater influence of industry and their own lack of resources, they pointed to another configurational factor that provides some counterbalance to the overwhelming power of industry. Industry and the Commission are afraid that if the CSOs are not included in governance, they will turn against nanotechnology and help to mobilize protests like the ones for genetically modified organisms (GMOs). This crucial factor suggests that the CSOs are more than a typical interest group because they connect with the broad consumer, labor, and environmental movements. As one of the trade union CSO interviewees commented, "Industry was hit hard and the Commission hit hard, and they wanted to avoid a second GMO disaster," and likewise an environmental CSO representative noted, "They thought that if they involve us...they can prevent another GMO nightmare." He went on:

Whenever you go to a nanotechnology conference, I think almost at any nanotechnology conference, you also hear about GMOs because they always say, "Oh, we have to take 
care that it doesn't develop in the same way as GMOs did." They still think GMOs were a great idea, but people just didn't understand it and the NGOs ruined everything.

The interviewee also noted that industry tracks media coverage of nanotechnology, and one industry representative noted a change in media coverage toward more negative stories after one of the prominent environmental organizations published a negative report on nanotechnology in food. This important linkage to the politically explosive topic of food was of concern, and industry was worried about the damage that CSOs could do if they turned solidly against nanotechnology. As the interviewee continued, "They saw that even with very little effort, the NGOs could achieve some change in the media landscape, so they're probably scared that we might scale up campaigning and they will lose the whole case."

Although CSOs could turn to an oppositional, grassroots approach, most CSOs are not opposed to the development of nanotechnology per se, and they are committed to working within the system to bring about an adequate regulatory framework. The potential health, environmental, and economic benefits of nanomaterials make the issue much more complicated than that of GMOs or pesticides in food. Furthermore, some of the CSOs involved in nanotechnology policymaking accept funding from the EU and national governments, and to some degree the funding sources constrain their strategies toward less contentious repertoires of action. Likewise, groups that have opted for more contentious strategies and for a moratorium on nanomaterials are excluded from participation in the governance process. The CSOs were aware of the radical flank organizations but also rejected their strategies. As one environmental CSO representative stated:

PMO [Pieces et main d'oeuvre] is...basically saying that you [industry and governments] have not consulted the society about whether we need it, and it just should not happen. They are the most radical, they are very vocal, and they have advocacy techniques close to guerrilla. And they manage to spend a lot of the debate in the discussions in which I am not favorable.

Thus, the CSOs distance themselves from the more radical viewpoints, but they are also aware that industry and the Commission are afraid of the potential for the CSOs to activate a more radical, grassroots, oppositional strategy.

With respect to the institutional dimension of the POS, there are also some openings, but CSOs again view the POS as generally favorable to industry. The primary institutional division that most CSOs mentioned was between the Commission and the Parliament, and this division was central in the political conflict over the definition of nanomaterials that was described above. One CSO representative summed up the views of many interviewees in the following comparison: "The European Parliament in general is closer to society [than the Commission] and...takes into account the concerns of the environment." Although the Parliament possesses legitimacy as the EU's only elected body, it lacks the full power of a traditional national government parliament, such as the capacity to lead legislation and to form a government. Thus, the CSOs view Parliament as an important source of countervailing power to the Commission 
and to industry, but they also recognize its weakness. As one environmental CSO representative commented, "The Parliament usually is quite a good body for regulation, but unfortunately they don't have that much power even if the Lisbon treaty gave them more power."

Another important institutional factor that provided an opportunity for CSO influence is the multiparty structure of Parliament. One adviser to a party in Parliament described the importance as follows:

[In the US], the minority [party] has no role to play, and due to the winner-takes-all system, you have a dual system which doesn't allow third voices. So therefore, I think that our system is more diverse, more reflecting of different views, and less dependent on industry. Of course, industrial interests are not entirely underrepresented and have a huge weight, but you can win against the chemical industry here, which is, I think, impossible in the US.

Of particular importance are the role of the Green Party in the European Parliament and its embrace of a precautionary approach to nanotechnology regulation. As the same adviser commented, "Clearly the Parliament is the more active player, and, yes, the Greens make a difference."

In contrast with the Parliament, the CSO leaders viewed the Commission as a whole as generally more closed to their perspectives. They noted that the Commission is committed to developing the nanotechnology industry as part of its goal of improving the European economy and the position of Europe in the world economy. As one environmental CSO representative commented:

The big, grand strategy of the EU is to be the most competitive region in the world, not to be the most sustainable region of the world. They...think that nanotechnology is a key technology to achieve this. So they put a lot of money into developing nanotechnologies, and they don't want to ruin this with too much regulation.

However, the CSOs also recognize that there are important divisions within the Commission and that the DG Environment can provide some support for a more precautionary approach to nanotechnology policy. As one environmental CSO representative stated:

There are often very big differences in approaches when it comes to DG Grow and DG Environment and what the line would be of the Commission. So here the internal fights are going on and well...we of course want to strengthen the position of DG Environment.

Because the CSOs have limited resources, they tend to focus them on DG Environment, but one government official noted that even this directorate receives more contacts from industry than from CSOs.

Although the DG Environment provides one source of opportunity for strategic influence on the Commission and, through the directorate, on the ECHA, the CSOs also perceived this 
directorate as a relatively weak ally. One environmental CSO representative commented that DG Environment "is only one DG, and the DG Grow is always more powerful." Another environmental CSO explained the problem in more detail:

\begin{abstract}
In my opinion DG Environment is very weak. It doesn't have any force to impose its own ideas and interests. It's very evident because when NGOs, trade unions, or some other bodies are close to DG Environment and propose the ideas of definitions and projects, DG Environment doesn't embrace them. They don't defend the environmental interests against DG Grow, DG Employment, DG SANCO, or whatever. It's also true that DG Grow is taking the lead. It has so much support from the industries, and so much research is coming from the industry as well. So DG Grow takes the final decision on the definition and on the rest of the nano policy.
\end{abstract}

An important implication of this imbalance of power is that although the ECHA is jointly governed by the DG Environment and DG Grow, the CSOs argued that the chemical agency tends to follow the perspective of DG Grow much more.

In summary, the CSOs pointed to the overwhelming influence of industry and to the proindustry perspective of the Commission, but they noted that the CSOs cannot be ignored completely because of the fear that both industry and the Commission have of triggering a grassroots social movement against nanotechnology. One CSO representative described the role of CSOs as defining agendas and problems rather than as affecting the implementation process. The CSOs were very cognizant of the two main institutional points of entry and support, Parliament and the DG Environment, but they also recognized that these allies were relatively weak in the context of the entire nanotechnology governance process.

The CSOs viewed the POS as relatively closed because the policymaking system was heavily dominated by the chemical industry, which had much higher levels of resources, and the ECHA also relied on its expertise. Furthermore, the general orientation of the Commission was also pro-industry and strongly supportive of the development of Europe's nanotechnology industry. However, the CSOs had various strategies for working within this relatively closed POS and for finding cracks in the wall that might lead to a more open POS. First, they could use their official stakeholder status to participate in policy deliberations and to urge other parties to arrive at compromise conditions. Second, they could form alliances with elements of the governance structure, especially Parliament and DG Environment, to achieve greater influence. Finally, they could play on the fear that the CSOs could turn against nanotechnology and mobilize social movements similar to the ones that appeared in opposition to GMOs.

\title{
Conclusions
}

Our approach suggests the value of a closer theoretical integration of STS work on scientized policy arenas and political sociological work on the POS. Because scientization involves the reliance on technical decision-making criteria in the policy process, it favors participation by groups with substantial expertise and capacity to mount technical arguments. Industry groups 
have both adequate expertise and the financial resources to deploy the expertise across a range of government organizations and throughout the policy process. As our interviews indicated, it was difficult for CSOs to develop detailed counterexpertise, both in terms of the adequacy of their expert knowledge and in terms of the resources to deploy that knowledge throughout the policy process. Thus, there is a close relationship between scientization and a relatively closed POS for CSO participation. When CSOs wish to widen the decision-making criteria to include a broader discussion of the environmental and societal implications of new technologies, or even to get relatively minor and scientized policy changes (such as the definition of nanomaterials), they find it difficult to overcome the resources and influence of industry.

To some degree public engagement mechanisms can mitigate the effects of scientization by opening up the policy process to broader decision-making criteria that emerge when public participation is solicited. However, the STS literature has questioned the political effectiveness of lay public engagement mechanisms such as consensus conferences or public consultations (Irwin 1995, 2006; Wynne 2007). These studies have shown that public engagement mechanisms may serve to legitimize or to modify only slightly decisions that have already been made elsewhere. Furthermore, the engagement of lay publics, especially when configured to exclude CSOs as stakeholders, can weaken the potential for CSOs to speak as representatives of the public (Hess 2011). In effect, public consultation mechanisms construct a public voice that can now compete with the capacity of public interest groups to speak for the public.

However, the exclusion of organized counterpublics from public consultation processes and from governance in general can lead to social movement mobilization, which in turn can weaken public support for technology policy that is favorable to industry. This problem is especially acute for the European Union, where the governing institutions other than the Parliament are not directly elected, and there is concern with a democracy deficit. Thus, a second order form of public participation can occur, where there is institutionalization of public participation from CSOs representing consumers, labor, and the environment. Although one might expect that institutionalized access to participation from organized public-interest groups would open the POS for policy changes that are favorable to the views of these groups, our research suggests that the CSOs view their effectiveness and success as limited due to the close relationship between political decision makers and industrial interest groups. Thus, the same limitations that the STS literature has found for lay participation mechanisms also appears for institutionalized participation from public-interest stakeholder groups.

Nevertheless, our conclusions are not entirely negative. Based on our research, we draw several conclusions about the conditions for CSOs to achieve success in a scientized and relatively closed POS where the issue involves strong monitoring and influence by industry. First, we suggest that institutionalized participation of CSOs in the technology policy process does not result in major changes in the POS and that instead CSOs are more likely to have success by building alliances with sympathetic actors in the government. In our previous research in the US, where the formal avenues for participation are weaker than in the EU, we found that the CSOs experienced similar frustration to that of the European CSOs (Hess 2010; Lamprou 2010). Despite the more favorable regulatory structure of $\mathrm{REACH}$ and the formal recognition of CSOs in 
the governance process of the EU, CSOs on both sides of the Atlantic described their work as an uphill battle against a very powerful chemical industry. Although having official stakeholder status can be helpful, our interviewees pointed to the importance of pursuing alliances with institutional actors such as the Parliament and DG Environment.

Second, we note that the presence of a mobilized mass movement would give the insider CSOs leverage against the power of industry that has formed an alliance with political leaders who support industrial innovation over safety concerns raised by public-interest organizations. This argument would certainly have good company, from the work of Piven and Cloward (1979) on the need for continuous disruptive politics to that of Skocpol (2014) on the failure of insider environmentalism that has turned its back on the grassroots. Furthermore, the explanation would be consistent in broad terms with other work on social movements and scientized policy fields. For example, in a study of colony collapse disorder in France and the US, Suryanarayanan and Kleinman (2014) identified the presence of a mobilized protest movement in France as one of the conditions of successful regulation of chemicals thought to cause honeybee death. Likewise, Europeans mounted much more extensive social movement mobilizations against GMOs than did their counterparts in the US, and GMO regulation was more comprehensive in Europe than in the US.

However, a closer look at both comparison cases suggests that by itself, social movement mobilization may not be an adequate condition for opening a POS. For example, Suryanarayanan and Kleinman suggest the importance of a more open epistemic culture in the regulatory politics of France, and likewise Schurman and Munro (2009) note that even where there were protests against GMOs in the US, various factors converged to make them less effective, including less concern with food quality and greater trust in regulators. Kinchy (2012) also shows that in Mexico grassroots mobilizations connected with indigenous rights were relatively ineffective in changing government policy on GMO food. Thus, even though contentious politics may be an important factor in strengthening the effectiveness of CSOs in technology policy negotiations, the importance of the factor will depend greatly on specific cultural and political contexts.

We also suggest that the absence of a broad grassroots social movement mobilization for nanotechnology policy is not necessarily a failure of movement strategy. Rather, it is closely connected with the public salience of the issue. Thus, our third main conclusion is that the potential to open a closed POS also depends on the level of public concern with the issue. When public concern is relatively low, it is more difficult to open up scientized decision making to broader issues of societal benefit and harm. CSO leaders noted that the regulation of nanomaterials is a difficult policy field for activists and advocates who wish to build interest and support from the public. In contrast, the issue of food is much more culturally sensitive than that of nanomaterials: food is ingested, closely connected to individual health, linked to preservation ethics associated with farms and nature, and deeply woven into cultural identities and social relations. Nanotechnology is emphatically not all of that. As a trade union CSO representative commented: 
If you ask everybody about GMOs, everybody knows and is against it, even if they know nothing because they have heard [about it] and they eat it...but nano, everybody thinks, "Oh, it's the things that they use and put in the computer." Like they don't understand.

Furthermore, the case of nanotechnology is complicated because it can potentially contribute to the amelioration of many environmental and health problems. Although there are configurations of GMO food that can also be beneficial, such as golden rice, in general the balance of benefits lies more with large, multinational corporations than with farmers and consumers. In contrast, most CSOs involved in the nanotechnology debate do not see the problem as a simple one of developing an oppositional campaign but instead as separating the benefits of nanotechnology from the unwanted side effects through better regulation.

Our fourth conclusion is that in order to open a POS within an existing governance process, CSOs must also be willing to explore the full range of institutionalized strategies. This viewpoint extends POS theory, which was developed in the context of the disruptive politics of social movements, by drawing attention to the range of institutionalized strategies as well. Litigation is a staple of American environmental politics, especially for the reformist organizations located in Washington. Some of the CSOs involved in EU-level nanotechnology policy engage in litigation, but this avenue is less prominent in Europe than in the US. As one CSO representative commented, "The Natural Resources Defense Council, which is one of the largest organizations in the US, went to court against the Food and Drug Administration for not regulating the BPA [bisphenol-A], but in the EU you cannot do that." In part the absence of the use of the courts as a strategy for change is due to the different opportunity structure in the judicial system in the EU and the US. However, the same person also explained that the less confrontational style of European NGOs is partly because in Europe "we have more faith that the state is going to take care of our interests and regulate it, while in the US there is more skepticism."

Related to this higher faith in the state was the absence of strategies that directly targeted chemical corporations. Our fifth conclusion is that in order to open a relatively closed POS, it is also necessary to target industrial actors directly. In the US we found that the relationship played a prominent role at least during the first phases of the development of nanotechnology regulation. In the relatively more closed POS of the US, Environmental Defense partnered with industry to experiment with private governance of nanotechnology (Bowman and Hodge 2008; Hess 2010). The 2007 EDF-Dupont Nano-Risk Framework sought to develop practices oriented toward the responsible development of nanoscale materials, and it was made available for companies and industry to inform the development of risk evaluations. These partnerships also carried risks of co-optation, and the voluntary strategy worked out by the EDF and DuPont created divisions among the CSOs (Hess 2010). Among the European CSOs, we found no evidence of any attempt to experiment with private-governance strategies or with direct oppositional mobilization. However, as Schurman (2004) showed, these strategies did appear in the European anti-GMO movement. 
In summary, we suggest that in the situation of a scientized decision-making process, public-interest CSOs may enhance their chances for opening a relatively closed POS, but both policymakers and CSOs should be wary of attempting to open the POS only by creating formal stakeholder mechanisms of participation. Rather, the strategies for opening the POS must pay attention to the underlying issue of the political power and influence of industry. The strategies that we have identified include engaging in disruptive and contentious protest, selecting aspects of an issue where public concern is most likely to be salient (e.g., the health effects of a new technology), and utilizing a wide range of institutional strategies such as litigation and direct pressuring of corporations. We do not reject the value of pursuing reforms of governance processes that institutionalize stakeholder participation; our research indicates that these changes provided some opportunities for the European CSOs. However, we argue that reforms of governance processes are themselves inadequate for scientized policy arenas where there is a strong role of industrial monitoring and lobbying that shapes policy outcomes. In this situation the other factors that we identified become more salient.

Although we suggest some avenues by which a blocked POS can be opened, it would be good to have additional research, especially across different policy issues, to explore the potential of these avenues and their limitations. There is no simple solution to the problem of finding opportunities in a partially blocked POS. If such a solution were easy to find, the dynamics of power in these circumstances would be significantly different. Instead, researchers must look for cracks in the wall, for the small openings that together might be pried open into bigger ones. The important "cracks in the wall" of the POS will likely vary across country and policy issue, and thus there is ample opportunity for future research on this topic. Research on this topic promises not only to bring a political sociological perspective into STS research on publics and technology policy, but it also promises to provide some practical implications for environmental and other reformers.

\section{Acknowledgements}

We also thank David Gee and Jeff Morris for providing assistance in making interview contacts and for other help with the project and Abby Kinchy, Dean Nieusma, Steve Breyman, and Ned Woodhouse for advice on the project.

\section{Funding}

This research is partially supported with funds from the National Science Foundation, Science and Technology Studies Program, for the doctoral dissertation research improvement grant "Toxic Chemicals, Environmental Organizations, and the Governance of Science and Technology in the E.U. and the US" (Award 1027074). Any opinions, findings, conclusions, or recommendations expressed in the article are those of the authors and do not necessarily reflect the views of the National Science Foundation or others who are acknowledged. 


\section{References}

Badaracco, J. 1985. Loading the Dice: A Five-country Study of Vinyl Chloride Regulation. Boston: Harvard Business School Press.

Bowman, D. and G. Hodge. 2008. "'Governing' Nanotechnology without Government?" Science and Public Policy 35(7): 475-487.

Broekhuizen, P. v., and L. Reijnders. 2011. “Building Blocks for a Precautionary Approach to the Use of Nanomaterials: Positions Taken by Trade Unions and Environmental NGOs in the European Nanotechnologies Debate." Risk Analysis 31(10): 1647-1647.

Buonsante, V. 2011. "Reshaping REACH." Paper presented at the REACH in Practice ERA Conference, Brussels, March 24.

Center for International Environmental Law. 2015. "Revision of REACH Annexes: Position Paper." Accessed Oct. 2, 2015, from http://www.ciel.org/wpcontent/ uploads/2015/10/ Position-Paper-REACH-Annexes-Final.pdf.

Daemmrich, A., and G. Krücken. 2000. "Risk versus Risk: Decision-making Dilemmas of Drug Regulation in the United States and Germany." Science as Culture 9(4): 505-534.

Delgado, A., K. Kjølberg, and F. Wickson. 2010. "Public Engagement Coming of Age: From Theory to Practice in STS Encounters with Nanotechnology.' Public Understanding of Science 20(6): 826-845.

Drori, G. S., \& Meyer, J. W. 2006. “Global Scientization: An Environment for Expanded Organization." In Globalization and organization: World society and organizational change, edited by G. Drori, J. Meyer, \& H. Hwang. Oxford, UK: Oxford University Press.

Duprez, L. 2011. "Nano Definition too Narrow says EEB - EEB." European Environment Bureau. Press Release. Accessed Oct. 2, 2015, from http:/ / www.eeb.org/index.cfm

Dür, A. 2008. "Interest Groups in the European Union: How Powerful Are They?" West European Politics 31(8): 1212-1230.

Dür, A., P. Bernhagen, and D. Marshall. 2013. "Interest Group Success in the European Union: When (and Why) Does Business Lose?" European Political Science Association Annual General Conference Paper 743. Accessed Oct. 2, 2015, http:/ / ssrn.com/abstract=2225099.

European Commission. 2001. "Commission of the European Communities: European Governance: A White Paper." Accessed Oct. 2, 2015, http://europa.eu/rapid/pressrelease_DOC-01-10_en.htm.

. 2008. "Commission of the European Communities: Communication from the Commission to the European Parliament, the Council, and the European and Social Committee: Regulatory Aspects of Nanomaterials." SEC (2008) 20136. Accessed Oct. 2, 2015, http:/ / eur-lex.europa.eu/LexUriServ/LexUriServ.do?uri=COM:2008:0366:FIN:en:PDF.

2011. "Commission Recommendation of 18 October 2011 on the Definition of Nanomaterial." Official Journal of the European Union L275: 38-40. Accessed Oct. 2, 2015, http:// eurlex.europa.eu/LexUriServ/LexUriServ.do?uri=OJ:L:2011:275:0038:0040:EN:PDF. 2012. "Communication from the Commission to the European Parliament, the Council 
and the European Economic and Social Committee: Second Regulatory Review on Nanomaterials." Brussels: European Commission. Accessed Oct. 2, 2015, http://eurlex.europa.eu/legal-content/EN/TXT/PDF/?uri=CELEX:52012DC0572\&from=EN.

European Environmental Bureau 2009. "EEB position Paper on Nanotechnologies and Nanomaterials: Small Scale, Big Promises, Divisive Messages." Accessed Oct. 2, 2015. http:/ / www.eeb.org/publication/2009/090217_EEB_nano_position_paper.pdf.

European Environmental Bureau, European Trade Union Confederation, Center for International Environmental Law. 2012. "Stakeholders' Response to the Communication on the Second Regulatory Review on Nanomaterials." Accessed Oct. 2, 2015, http:/ / www.ecostandard.org/ ?p=935.

European Parliament. 2009. Report on the Regulatory Aspects of Nanomaterials: (2008/2208(INI)). Brussels: $\quad$ European Parliament. http:/ / www.europarl.europa.eu/ sides / getDoc.do?pubRef=/ / EP / / TEXT+REPORT+A6-2009-0255+0+DOC+XML+V0/ / EN.

Fedrigo, D., and R. Senjen. 2010. Shaping Innovation: Policy Approaches on Innovation Governance: Issue 4. EEB. Accessed Oct. 2, 2015, http:// www.eeb.org/EEB/?LinkServID=FBEF1E68F364-600E-D2DD41B9CA0FA4EF.

Frickel, S. and K. Moore, (Eds). 2006. The New Political Sociology of Science: Institutions, Networks, and Power. Madison, WI: University of Wisconsin Press.

Greenwood, J. 2007. "Organized Civil Society and Democratic Legitimacy in the European Union." British Journal of Political Science 37(2): 337-357.

2011. Interest Representation in the European Union. London: Palgrave Macmillan.

Groves, C. 2011. "Public Engagement and Nanotechnology in the UK: Restoring Trust or Building Robustness?" Science and Public Policy 38(10): 783-793.

Hagendijk, R., and A. Irwin. 2006. "Public Deliberation and Governance: Engaging with Science and Technology in Contemporary Europe." Minerva 44(2): 167-184.

Hess, D. J. 2010. "Environmental Reform Organizations and Undone Science in the United States: Exploring the Environmental, Health, and Safety Implications of Nanotechnology." Science as Culture 19(2): 181-214.

2011. "To Tell the Truth: On Scientific Counterpublics." Public Understanding of Science 20(5): 627-641.

Hodge, G. A., D. Bowman, and K. Ludlow, (Eds.) 2007. New Global Frontiers in Regulation: The Age of Nanotechnology. Cheltenham, UK: Edward Elgar Publishing.

Irwin, A. 1995. Citizen Science: A Study of People, Expertise, and Sustainable Development. New York: Routledge.

. 2006. "The Politics of Talk: Coming to Terms with the 'New' Scientific Governance." Social Studies of Science 36(2): 299-320.

Jasanoff, S. 1986. Risk Management and Political Culture: A Comparative Study of Science in the Policy Context. New York, NY: Russell Sage Foundation.

Joint Research Center 2011. REACH Implementation Project Substance Identification of Nanomaterials (RIP-oN 1) (Advisory Report). Brussels: European Commission. Accessed Oct. 2, 2015, 
http:/ / ec.europa.eu/environment/ chemicals/nanotech/pdf/report_ripon1.pdf.

Kinchy, A. 2012. Seeds, Science, and Struggle: The Global Politics of Transgenic Crops. Cambridge, MA: The MIT Press.

Kitschelt, H. 1986. "Political Opportunity Structures and Political Protest: Anti-Nuclear Protest in Four Democracies." British Journal of Political Science 16: 57-85.

Kleinman, D. and A. Kinchy. 2003. "Why Ban Bovine Growth Hormone? Science, Social Welfare, and the Divergent Biotech Policy Landscapes in Europe and the United States." Science as Culture 12 (3): 375-414.

Kriesi, H. 2004. "Political Context and Opportunity." In The Blackwell Companion to Social Movements, edited by D. Snow, S. Soule, and H. Kriesi, 67-90. Malden, MA: Blackwell.

Lamprou, A. 2010. “Nanotechnology Regulation: Policies Proposed by Three Organizations for the Reform of the Toxic Substances Control Act." Studies in Sustainability. Chemical Heritage Foundation. <http://www.chemheritage.org/community/store/whitepapers/studies-in-sustainability/nanotechnology-regulation.asp $x>, \quad$ accessed 23 February 2016.

Levidow, L., and C. Marris. 2001. "Science and Governance in Europe: Lessons from the Case of Agricultural Biotechnology." Science and Public Policy 28(5): 345-360.

Liebert, U., and H. Trenz 2011. The New Politics of European Civil Society. London and New York: Routledge.

Mahoney, C. 2008. Brussels versus the Beltway: Advocacy in the United States and the European Union. Washington, D.C.: Georgetown University Press.

McAdam, D., S. Tarrow, and C. Tilley. 2001. Dynamics of Contention. Cambridge, U.K.: Cambridge University Press.

Meyer, D. 2004. "Protest and Political Opportunities." Annual Review of Sociology 30: 125-145.

Philbrick, M., and J. Barandieran. 2009. “The National Citizens' Technology Forum: Lessons from the Future." Science and Public Policy 36(5): 335-347.

Piven, F., and R. Cloward. 1979. Poor People's Movements: Why They Succeed, How They Fail. New York: Vintage Books.

Rogers-Hayden, T., and N. Pidgeon. 2007. “Moving Engagement 'Upstream'? Nanotechnologies and the Royal Society and Royal Academy of Engineering's Inquiry." Public Understanding of Science 16(3): 345-364.

Ruzza, C. 2004. Europe and Civil Society: Movement Coalitions and European Governance. Manchester and New York: Manchester University Press.

Ruzza, C. and E. Bozzini 2008. “Organized Civil Society and Routes of Governance: Organized Contestation." European Political Science 7(3): 296-303.

Sarewitz, D. 2004. "How Science Makes Environmental Controversies Worse." Environmental Science and Policy 7(5): 385-403.

Schurman, R. 2004. "Fighting 'Frankenfoods': Industry Opportunity Structures and the Efficacy of the Anti- Biotech Movement in Western Europe. Social Problems 51(4): 243-268.

Schurman, R., and W. Munro. 2009. "Targeting Capital: A Cultural-Economy Approach to Understanding the Efficacy of Two Anti-Genetic Engineering Movements." American 
Journal of Sociology 115(1): 155-202.

Senjen, R. 2009a. Challenges and Opportunities to Green Nanotechnologies: Issue 1. European Environmental Bureau. Accessed Oct. 2015, http:/ / www.bef.lt / fileadmin/Publications / 2009-NanoBrochureNo1-WEB_Eng.pdf. . 2009b. Nanomaterials - Health and Environmental Concerns: Issue 2. European Environmental Bureau. Accessed Oct. 2, 2015, http://www.eeb.org/EEB/?LinkServID=540E4DA2D449-3BEB-90855B4AE64E8CE6.

. 2009c. A Critical Review of Governance Issues in Europe and Elsewhere: Issue 3. European $\begin{array}{lllll}\text { Environmental } \quad \text { Bureau. } & \text { Accessed } & \end{array}$ http:/ / www.bef.lt / fileadmin/Publications / 2009-NanoBrochureNo3-WEB_Eng.pdf.

Skocpol, T. 2014. "Making Sense of the Past and Future of Global Warming Politics in the United States." European University Institute, Max Weber Lecture 2014/04. Accessed Dec. 13, 2015.

http:/ / cadmus.eui.eu / bitstream/handle/1814/33212/LS_MWP_2014_04.pdf?sequence= 1 .

Sanarayanan, S. and D.L. Kleinman. 2014. "Beekeepers' Collective Resistance and the Collective Politics of Pesticide Resistance in the United States." Political Power and Social Theory 27: 89-122.

Trenz, H., Bernhard, N., and Jentges, E. 2011. "Civil Society and EU Constitution Making." In The New Politics of European Civil Society, edited by U. Liebert and H. Trenz, 123-142. New York: Routledge.

Vogel, D. 1986. National Styles of Regulation: Environmental Policy in Great Britain and the United States. Ithaca, NY: Cornell University Press.

Warleigh, A. and J. Fairbrass, (Eds.) 2002. Influence and Interests in the European Union: The New Politics of Persuasion and Advocacy. London: Europa Publications.

Wynne, B. 2007. "Public Engagement as a Means of Restoring Public Trust in Science: Hitting the Notes, but Missing the Music?" Community Genetics 9(3): 211-220. 